\title{
IRRIGATION ENERGY CONSUMPTION IN A TROPICAL LOWLAND RICE
}

\section{FIELD}

\author{
M.M.M. Najim ${ }^{1}$, M. Aminul Haque ${ }^{2}$ and S.M. Bockari-Gevao ${ }^{3}$
}

\begin{abstract}
Available and limited water resources are seeing high demand from many sectors such as agriculture, industry and domestic households. In water allocation, the quantification of water in terms of energy used for water supply is more appropriate in terms of economic aspects. This study was undertaken to assess the embodied in irrigation for a lowland tropical rice production system. The irrigation energy requirements for the off and main cropping seasons were estimated based on crop water requirements at different cropping stages. Experimental results indicate that there are significant differences among the irrigation energy requirements of the various cropping stages, with the highest values of 4625.34 MJ ha $\mathrm{MJ}^{-1}$ and $3843.93 \mathrm{MJ} \mathrm{ha}^{-1}$ observed for the mid-season stage in the off-season and main season, respectively. The off-season irrigation energy requirements for the rice variety MR 219 were found to be 32.6\%, 26.8\%, 20.3\% and 271.7\% higher than the main season for the initial stage, crop development stage, mid-season stage and late-season stage, respectively. There is a significant difference in irrigation energy requirement among the seasons and crop growth stages. Crop Water Use Efficiency (CWUE) in the off season (0.26 $\left.\mathrm{kg} / \mathrm{m}^{3}\right)$ is higher than the CWUE in the main season $\left(0.23 \mathrm{~kg} / \mathrm{m}^{3}\right)$ which is attributed to better water management and yields during the off season due to water shortage. Irrigation energy productivity (IEP) of rice in the off season and the main season at Tanjong Karang is 0.26 and 0.29, respectively. In terms of irrigation energy spent, the main season shows better performance where a part of irrigation requirement is met by rainfall. Irrigation energy, CWUE and IEP can be used in decision making on the profitability of growing rice in different seasons.
\end{abstract}

Key Words: Irrigation, Energy, Season, Growth Stage, Rice

\section{INTRODUCTION}

Irrigation is extremely useful to improve crop yields. Different kinds of pumping and distribution networks are needed in conveying water to meet crop demand at appropriate time. Musick et al. (1994) showed the wheat yield increment from $2.8 \mathrm{t} \mathrm{ha}^{-1}$ to $8.2 \mathrm{t} \mathrm{ha}^{-1}$ with irrigation. Udagedara and Najim (2009) reported that the land area under paddy cultivation is much lesser in the Yala season compared to the Maha season due to unavailability of irrigation water.

Energy is required for all irrigation systems, except that those relying totally on gravity flow which may require less energy with most of the necessary energy only used for equipment and facilities. Considerable energy losses occur due to pipe friction, pump inefficiency, motor inefficiency, pressure drops at sprinklers or other application devices, etc.. Total amounts of water applied to the field to

\footnotetext{
${ }^{1}$ Senior Lecturer, Environmental Conservation and Management Degree Program, Faculty of Science, University of Kelaniya, Kelaniya. Sri Lanka.

${ }^{2}$ Water Resources Planning Organization (WARPO), Ministry of Water Resources, House No. 103, Road No. 1, Banani, Dhaka-1213. Bangladesh.

${ }^{3}$ Department of Agricultural Engineering, Njala University College, University of Sierra Leone, Freetown, Sierra Leone.
} 
meet the crop water requirement and other beneficial uses are not used for the intended purpose. A portion of water is always lost that could be expressed as loss of energy too.

Available and limited water resources are seeing high demand from many sectors such as agriculture, industry and domestic households. Agriculture becomes much more energy intensive when irrigation is used. Numerous examples have indicated that irrigation may raise direct energy requirements to as much as 10 times that required for agricultural machinery alone (Fluck and Baird, 1980). Johnson and Henderson (1977) calculated fuel requirements ranging from 11666 to 66408 $\mathrm{MJ} \mathrm{ha}^{-1}$ for center pivot irrigation systems and 3659 to $41953 \mathrm{MJ} \mathrm{ha}^{-1}$ for gravity distributed systems. Fluck and Baird (1980) calculated average direct energy requirements for center pivot irrigation as being $23629 \mathrm{MJ} \mathrm{ha}^{-1}$ for the United States. Batty et al. (1975) reported that installation (indirect) energy of an irrigation system represents only 5 to $27 \%$ of direct (pumping) energy costs. Chaudhary et al. (2009) reported that the raised bed sowing of wheat saved up to $4.2 \%$ irrigation energy when cultivated with rotation of rice and other crops. Pathak and Bining (1985) reported that the energy consumption in rice production was found to be much higher than that of wheat production, primarily due to the high irrigation requirements of rice. Therefore, the quantification of water in terms of energy is more appropriate than using water quantity figures alone which do not give any sense of economic values.

Recently, serious efforts have been made by the government of Malaysia to reduce the dependence of lowland rice farmers on rain by providing them with irrigation facilities from surface and subsurface water resources. In some cases, farmers complain that irrigation water is not available to them in proper amounts at the appropriate time, resulting in low crop production. Sometime the supply of water is in excess, while during some periods of the crop growing seasons, canals do not carry water at all, in spite of the high supply requirements by farmers. Even if the water flows in the canal, farmers at the tail end do not always get water, and usually receive small amounts, which often result in low productivity.

The main objective of this study was to assess the irrigation energy consumption pattern of a lowland rice production system in Malaysia. The specific objectives were to determine the irrigation energy requirements at each stage of the lowland rice production system; to compare the irrigation energy requirements among the cropping stages; and to determine the seasonal effect on the irrigation energy requirements of each cropping stage.

\section{MATERIALS AND METHODS}

The study was carried out in the off season (January to July) and main season (August to December) in 2003 at the Sungai Burong Compartment of the Tanjong Karang Rice Irrigation Scheme in the Kuala Selangor and Sabak Bernam Districts of Malaysia with the view of assessing the irrigation energy requirements at different cropping stages (land preparation stage, initial stage, crop development stage, midseason stage and late-season stage) in a lowland rice production system. In the study area, the farmers rely totally on irrigation water supplied by gravity flow from the central irrigation system under the management of the Department of Irrigation and Drainage (DID), Malaysia. During the land 
preparation period, supplemental irrigation water was pumped into the field because the irrigation supply from the central irrigation system did not reach the experimental field on time as the field was located at the tail-end of the irrigation canal running from the main source of water supply. In the study area land preparation was accomplished by three rotary tillage passes, namely: first rotavation, second rotavation and third rotavation. Normally, the first rotavation is carried out under dry conditions, while the second and third rotavations were done under flooded field conditions. The field was therefore irrigated before commencement of the second rotavation by pumping water using a propeller pump, Yanmar L60AE-DPATM, driven by a $4.4 \mathrm{~kW}$ air-cooled diesel engine. Throughout the rice growing period, there was standing water in the field to an average depth of 10 to $15 \mathrm{~cm}$. This water was drained out of the field two weeks before commencement of the harvesting operation with a rice combine harvester.

The energy required to deliver water to the field during the land preparation period via a pumping system was estimated by the following equation (Intaravichai, 1998):

$$
\text { PUMPEN }=\frac{\text { FLOWRATE } * \text { TDH }}{270 * \text { PEFY }}
$$

where PUMPEN is the energy input in water pumping $(\mathrm{kW})$; FLOWRATE is the flow rate of the pump $\left(\mathrm{m}^{3} \mathrm{~h}^{-1}\right)$; TDH is the total dynamic head $(\mathrm{m})$; and PEFY is the pump efficiency (decimal).

The irrigation energy requirements for the four distinct crop growth stages, namely: initial stage, crop development stage, mid-season stage and late-season stage, were estimated based on the crop water requirement at each stage.

Climatic data for the period 1998 to 2003, which included maximum and minimum daily air temperature, maximum and minimum daily relative humidity, wind speed, pan evaporation, and rainfall for the two cropping seasons were obtained from the Malaysian Meteorological Services. Crop evapotranspiration, crop water requirements, and net irrigation requirements were then estimated for the crop growing seasons. The reference evapotranspiration $\left(\mathrm{ET}_{\mathrm{o}}\right)$ was calculated by the Class-A pan evaporation method (Richard et al., 1998). The Class-A pan evaporation method has been well recognized in comparative studies and for practical irrigation scheduling. It is also reported that the Class-A pan evaporation method is a more reliable method of estimating reference evaporation than other methods for rice crop. Open pans provide a more satisfactory means of estimating $\mathrm{ET}_{0}$ and, hence evapotranspiration of rice under flooded conditions than any other available technique. The equation used in the Class-A pan-evaporation method is as follows:

$$
\mathrm{ET}_{\mathrm{o}}=\mathrm{K}_{\mathrm{p}} * \mathrm{E}_{\mathrm{pan}}
$$

where $\mathrm{ET}_{\mathrm{o}}$ is the reference crop evapotranspiration $\left(\mathrm{mm} \mathrm{d}^{-1}\right) ; \mathrm{K}_{\mathrm{p}}$ is the pan coefficient (dimensionless); and $\mathrm{E}_{\mathrm{pan}}$ is the pan evaporation $\left(\mathrm{mm} \mathrm{d}^{-1}\right)$.

In the present study, the $\mathrm{K}_{\mathrm{p}}$ value was estimated according to FAO Irrigation and Drainage Paper No.56 guidelines (Richard et al., 1998) using the following equation: 


\section{$\mathrm{K}_{\mathrm{p}}=0.108-0.0286 \mathrm{u}_{2}+0.0422 \ln (\mathrm{FET})+0.1434 \ln \left(\mathrm{R}\right.$ there $\mathrm{ET}_{\mathrm{c}}$ is the actual crop $-0.000631\left[\ln (\mathrm{FET})^{2} * \ln \left(\mathrm{RH}_{\text {mean }}\right)\right]$ \\ where $\mathrm{K}_{\mathrm{p}}$ is the pan coefficient evapotranspiration $\left(\mathrm{mm}\right.$ day $\left.^{-1}\right) ; \mathrm{ET}_{\mathrm{o}}$ is the reference crop evapotranspiration $\left(\mathrm{mm} \mathrm{day}{ }^{-1}\right)$; and $\mathrm{K}_{\mathrm{c}}$ is the crop coefficient (dimensionless).} (dimensionless); $\mathrm{u}_{2}$ is the wind speed at $2 \mathrm{~m}$ above ground surface $\left(\mathrm{m} \mathrm{s}^{-1}\right)$; FET is the fetch, assumed to be $1000 \mathrm{~m}$; and $\mathrm{RH}_{\text {mean }}$ is the mean relative humidity of the study area $(\%)$. The wind speed $\left(\mathrm{u}_{2}\right)$ at the $2 \mathrm{~m}$ height was calculated by the following equation:

$$
\mathrm{u}_{2}=\mathrm{u}_{\mathrm{z}}\left[\frac{4.87}{\ln (67.8 * \mathrm{z}-5.42)}\right]
$$

where $\mathrm{u}_{\mathrm{z}}$ is the measured wind speed at $\mathrm{Z} \mathrm{m}$ above the ground surface $\left(\mathrm{m} \mathrm{s}^{-1}\right)$; and $\mathrm{z}$ is the height of measurement above ground surface $(\mathrm{m})$. The mean relative humidity $\left(\mathrm{RH}_{\text {mean }}\right)$ was approximated from air temperature as:

$\mathrm{RH}_{\text {mean }}=50 * \frac{\mathrm{e}^{\mathrm{o}}\left(\mathrm{T}_{\text {min }}\right)}{\mathrm{e}^{\mathrm{o}}\left(\mathrm{T}_{\text {max }}\right)}+50$

where $\mathrm{e}^{\mathrm{o}}\left(\mathrm{T}_{\min }\right)$ is ) saturation vapor pressure at the minimum air temperature $[\mathrm{kPa}]$ and $\mathrm{e}^{\mathrm{o}}\left(\mathrm{T}_{\max }\right)$ is saturation vapor pressure at the maximum air temperature $[\mathrm{kPa}]$.

Actual crop evapotranspiration under standard conditions was then calculated as the product of $\mathrm{ET}_{\mathrm{o}}$ and the crop coefficient $\left(\mathrm{K}_{\mathrm{c}}\right)$ using equation (6). Due to the differences in evapotranspiration during the various crop growth stages, the $\mathrm{K}_{\mathrm{c}}$ for a given crop will vary over the growing period. $\mathrm{K}_{\mathrm{c}}$ values ranging from 1 to 1.35 for the rice variety MR 219 were used based on Chan and Cheong (2001).

$$
\mathrm{ET}_{\mathrm{c}}=\mathrm{ET}_{\mathrm{o}} * \mathrm{~K}_{\mathrm{c}}
$$

The following equation was used to determine the amount of irrigation water required at each of the crop growth stages:

$$
\mathrm{IR}=\mathrm{ET}_{\mathrm{c}}+\text { LOSS }-\mathrm{ERF}
$$

where IR is the irrigation requirement at each of the crop growth stage $\left(\mathrm{mm} \mathrm{d}^{-1}\right)$; LOSS is the losses during each of the crop growth stages due to percolation and seepage $\left(\mathrm{mm} \mathrm{d}^{-1}\right)$, assumed as 3 $\mathrm{mm} \mathrm{d}^{-1}$ for the study area (ADB, 1992); and ERF is the mean effective rainfall for a particular crop growth stage $(\mathrm{mm}$ $\left.\mathrm{d}^{-1}\right)$.

The irrigation energy consumption at each crop growth stage was then calculated as:

$\mathrm{IRER}=\frac{\mathrm{IR} * \mathrm{~L} * \mathrm{IRF}}{\mathrm{AREA}}$

where IRER is the irrigation energy requirement at each crop growth stage (MJ ha ${ }^{-1}$ ); L is the length of crop growth stage (day); IRF is irrigation energy factor ( $\mathrm{MJ} \mathrm{mm}{ }^{-1}$ ), assumed to be $6.34 \mathrm{MJ} \mathrm{mm}^{-1}$ (Rutger and Grant, 1980); and AREA is the crop area (ha).

IRER can be related to the crop water use efficiency (CWUE) which is given as

$$
C W U E=\frac{Y}{\mathrm{CWR}}
$$

where CWR is crop water requirement $(\mathrm{mm} / \mathrm{ha})$ and $\mathrm{Y}$ is the yield $(\mathrm{kg} / \mathrm{ha})$. The yield and IRER (MJ/ha) can also be 
linked to the irrigation energy productivity (IEP) (kg/MJ).

$\mathrm{IEP}=\frac{Y}{\mathrm{IRER}}$

\section{RESULTS AND DISCUSSION}

The average crop evapotranspiration was found to be $5.11 \mathrm{~mm} \mathrm{~d}^{-1}$ and 4.09 $\mathrm{mm} \mathrm{d}^{-1}$ for the off-season and main season, respectively. Crop evapotranspiration was higher during the off-season compared to the main season mainly as a result of differences in prevailing weather conditions in the two seasons. The average irrigation water requirement for a season is 120 $\mathrm{cm} \mathrm{ha}^{-1}$ where $200 \mathrm{~mm}$ is used as land preparation water requirement and 4 $\mathrm{mm}$ of seepage and percolation loss in a day. Pimentel and Pimentel, (1996) reported that the water requirement of rice in the United States is $250 \mathrm{~cm}$.

The total irrigation energy requirement at Tanjong Karang rice irrigation scheme in the off season and the main season are $12383.54 \mathrm{MJha}^{-1}$ and 9341.22 $\mathrm{MJha}^{-1}$. Off season requires more irrigation as the rainfall is less and the crop evapotranspiration is higher comparative to the main season. Irrigation energy requirement for rice production in the United States is 8949.6 MJ (18.1\% of the total energy requirement) (Pimentel and Pimentel, 1996) which is almost similar to the irrigation energy requirement at Tanjong Karang in the main season. Irrigation energy required to produce tomatoes is $4225.8 \mathrm{MJ} / \mathrm{ha}$ ( $3.1 \%$ of the total energy requirement), which is far below the irrigation energy required by rice. This is mainly due to the nature of rice cultivation where a standing water level is maintained in the soil to provide many other benefits for the crop and water management which increases the amounts of water lost from the field.

The estimated irrigation energy requirements at the various cropping stages in the off- and main seasons are given in Table 1. The analysis of variance given in Table 1 indicates that there are significant differences $(p<0.05)$ among the irrigation energy requirements of the various cropping stages, with the highest values observed for the mid season stage, followed by the crop development stage in both the off- and main seasons. The mid-season stage and the crop development stage are the most sensitive periods to water shortage. Decrease in irrigation supply within these two periods could lead to a sharp decrease in yield. The irrigation energy requirements within these periods could only be reduced by minimizing losses from the fields through proper irrigation water management. Further, the water level within field plots could be kept at the lowest level and maintained precisely so that rainfall could be utilized effectively, thereby reducing the water requirement for irrigation. In the offseason, the irrigation energy requirements for the initial stage and the late season stage were, however, not significantly different from each other, while insignificant difference between the energy requirements for land preparation and the initial stage was also observed in the main season. There was no significant difference in irrigation energy use for land preparation in both seasons mainly because it was based on pumping and fixed duration allocated for the land preparation which usually has to be completed within 14 days within the irrigation system. Further, the evapotranspiration and other losses such as seepage and percolation are not 
widely varying between off and main seasons. Land preparation is usually carried out within a period of two weeks, irrespective of cropping season.
The water requirement at this stage is expected to be the same for both the seasons.

Table 01: Analysis of variance of irrigation energy requirements in the off-season and the main season

\begin{tabular}{lccc}
\hline \multicolumn{1}{c}{ Cropping Stage } & \multicolumn{3}{c}{ Irrigation Energy $\left(\mathrm{MJ} \mathrm{ha}^{-1}\right)$} \\
\cline { 2 - 4 } & Off-Season & Main Season & Average \\
\hline Land Preparation & $1106.00^{\mathrm{d}}$ & $1106.61^{\mathrm{c}}$ & $1106.3^{\mathrm{d}}$ \\
Initial Stage & $1651.02^{\mathrm{c}}$ & $1245.53^{\mathrm{c}}$ & $1448.3^{\mathrm{c}}$ \\
Crop Development Stage & $3461.56^{\mathrm{b}}$ & $2730.89^{\mathrm{b}}$ & $3096.2^{\mathrm{b}}$ \\
Mid-Season Stage & $4625.34^{\mathrm{a}}$ & $3843.93^{\mathrm{a}}$ & $4234.6^{\mathrm{a}}$ \\
Late-Season Stage & $1539.62^{\mathrm{c}}$ & $414.26^{\mathrm{d}}$ & $976.9^{\mathrm{d}}$ \\
Overall Mean & 2476.7 & 1868.2 & 2172.5 \\
$\mathrm{R}^{2}$ & 0.964 & 0.983 & 0.916 \\
\hline
\end{tabular}

Values in a given column followed by the same letter are not significantly different at the 0.05 level.

The t-test comparison of irrigation energy requirements presented in Table 1 show that more energy is consumed in the offseason than in the main season for all the cropping stages, except for land preparation. The off-season irrigation energy requirements were found to be $32.6 \%, 26.8 \%, 20.3 \%$ and $271.7 \%$ higher than the main season for the initial stage, crop development stage, mid-season stage and late-season stage, respectively for the rice variety MR 219. The higher mean evapotranspiration during the off season requests a higher irrigation volume increasing the irrigation energy requirement. Usually a component of the irrigation water requirement in the main season is met by rainfall. Water supply to rice fields in the off-season mainly depends on irrigation. This requirement renders off-season crop production more expensive in terms of irrigation energy requirement. The high cost incurred through more expenditure of energy for irrigation must be compensated by achieving a higher yield; otherwise, profitability of rice production in the off season will be questionable.
Table 2 shows the crop water use efficiency (CWUE) and irrigation energy productivity (IEP) in the off season and the main season at the study site. Improvement of CWUE of crop cultivars is important under water deficient conditions so that plants can grow and yield well. CWUE in the off season (0.26 $\mathrm{kg} / \mathrm{m}^{3}$ ) is higher than the CWUE in the main season $\left(0.23 \mathrm{~kg} / \mathrm{m}^{3}\right)$. More water is used in the off season due to dry weather conditions but the better climatic conditions have given better yields comparative to the main season. Wheat, a highland crop, in a Mediterranean type environment has shown a higher CWUE of $1.27 \mathrm{~kg} / \mathrm{m}^{3}$ (French and Schultz, 1984) but rice, a lowland crop with a standing water level in the field, shows lower CWUE due to more losses in terms of evaporation from standing water surface, seepage and percolation.

Higher CWUE shows that water is more efficiently used in the off season than that of the main season. Hatfield et al. (2001) reports that CWUE can be improved through the precipitation use efficiency. One of the reasons for the higher CWUE 
reported in the off season from Tanjong Karang could be better utilization of the rainfall. Irrigation energy productivity of rice in the off season and the main season at Tanjong Karang is 0.26 and 0.29 , respectively. In terms of irrigation energy spent, the main season shows better performance as a part of irrigation requirement is met by rainfall.

Table 02: Crop water use efficiency and irrigation energy productivity in the off season and the main season

\begin{tabular}{lrr}
\hline & Off-Season & Main Season \\
\hline Total Irrigation Energy $\left(\mathrm{MJ} \mathrm{ha}^{-1}\right)$ & 12383.5 & 9341.2 \\
Total CWR $(\mathrm{mm} / \mathrm{ha})$ & 1262 & 1143 \\
Average Yield $(\mathrm{kg} / \mathrm{ha})$ & 3230.6 & 2671.8 \\
CWUE $(\mathrm{kg} / \mathrm{mm})\left(\mathrm{kg} / \mathrm{m}^{3}\right)$ & $2.56(0.26)$ & $2.34(0.23)$ \\
IEP $(\mathrm{kg} / \mathrm{MJ})$ & 0.26 & 0.29 \\
\hline
\end{tabular}

\section{CONCLUSIONS}

Irrigation energy requirement represents the water requirement as an energy requirement which can easily be converted into monetary terms. This study shows that there is a significant difference in irrigation energy requirement among the crop growth stages and the mid season stage requires the highest irrigation energy. Irrigation energy requirement for paddy production is higher in the off season compared to the main season in Tanjong Karang that reflects the high crop water requirement. Off season requires more irrigation as the rainfall is less and the crop evapotranspiration is higher comparative to the main season. CWUE in the off season at Tanjong Karang is higher than the CWUE in the main season. Even though more water is used in the off season due to dry weather conditions, the better climatic conditions prevailing have given better yields comparative to the main season. CWUE could be combined with irrigation energy requirement to compare the efficient water and energy use that can be used in selecting economical crops for a particular area.

\section{REFERENCES}

Asian Development Bank (ADB) (1992) Northern Terengannu Rural Development Project (Phase- II), Malaysia. Interim Report.

Batty, J., S.N. Hamad and J. Keller (1975) Energy inputs to irrigation. Journal of Irrigation and Drainage 110 (IR4), pp: 293-307.

Chan, C.S. and A.W. Cheong (2001) Seasonal water effects on crop evapotranspiration and rice yield. Journal of Tropical Agriculture and Food Science 29 (1), pp: 77 - 92.

Chaudhary, V.P., B. Gangwar, D.K. Pandey, and K.S.Gangwar (2009) Energy auditing of diversified rice-wheat cropping systems in Indo-gangetic plains. Energy, 34(9),pp: 1091-1096. 
Fluck,R.C. and C.D.Baird (1980) Agricultural Energetics. The AVI Publishing Company Inc., Westport, Connecticut.

French R.J. and J.E. Schultz (1984) Water use efficiency of wheat in a Mediterranean-type environment. I. The relation between yield, water use and climate, Australian Journal of Agricultural Research, 35(6), pp: $743-764$.

Hatfield, J.L., T.J. Sauer and J,H.Prueger (2001) Managing Soils to Achieve Greater Water Use Efficiency, Agronomy Journal, 93, pp: 271-280.

Intaravichai, P. (1998) Energy analysis in mechanized rice production system: specifically for Central Thailand. PhD Thesis (Unpublished). Universiti Putra Malaysia, Malaysia.

Johnson, B.B. and P.A. Henderson (1977) Energy price levels and the economics of irrigation. Dep. of Agric. Econ. Rept. No. 79A. Univ. of Neb., Lincoln.

Musick, J.T., O.R. Jones, B.A. Stewart and D.A. Dusek (1994) Water-yield relationships for irrigated and dryland wheat in the U.S. Southern plains, Agronomy Journal 86(6), pp: 980-986.

Pathak,B.S. and A.S. Bining (1985) Energy use pattern and potential for energy saving in rice-wheat cultivation. Energy in Agriculture. 4, pp: 271-278

Pimentel,D. and M.Pimentel (1996) Food, Energy and Society. Colorado University Press, Niwot, CO.

Richard, G.A., L.S. Pereira, D. Raes and M. Smith (1998) Crop evapotranspiration: Guidelines for computing crop water requirements. FAO Irrigation and Drainage Paper No. 56. Rome, Italy.

Rutger,J.N. and W.R. Grant (1980) Energy use in rice production. In. Pimentel, D. (Ed.), Handbook of Energy Utilization in Agriculture. CRC Press, Inc. Boca Raton, Florida. pp:93- 98.

Udagedara, U.S.C. and M.M.M. Najim (2009) Potential to Increase the Area under Paddy Cultivation with Domestic and Municipal Wastewater Irrigation in Kurunegala District. In: Proceedings of the National Conference on Water, Food Security and Climate Change in Sri Lanka. Pp:157-165. Editors: A. Evans and K. Jinapala, International Water Management Institute. Colombo, Sri Lanka. 